\title{
Metabolism of human femoral head cartilage in osteoarthrosis and subcapital fracture
}

\author{
D. Mitrovic, M. GRUSON, J. DEMIGNON, Ph. MERCIER, F. APrile, \\ AND S. DE SEZE
}

From Research Unit 18 of INSERM, Department of Rheumatology, Lariboisì̀re Hospital, Paris

SUMMARY The cell density and incorporation of ${ }^{35} \mathrm{SO}_{4}$ and ${ }^{3} \mathrm{H}$-glycine into human articular cartilage from 8 osteoarthrotic and 7 normal (subcapital fracture) femoral heads were studied. It was found that osteoarthrotic cartilage incorporates on a per cell basis about twice as much ${ }^{35} \mathrm{SO}_{4}$ and ${ }^{2-5}$ times as much ${ }^{3} \mathrm{H}$-glycine as normal cartilage. There was no relationship between the intensity of incorporation and either the location of the cartilage (weight-bearing versus non weight-bearing $ᄋ$ areas) in normal cartilage or the degree of damage (normal-like, fibrillated, and ulcerated) in osteoarthrotic articular cartilage. In the latter tissue the increased synthetic capacity of the cells seems to be a diffuse rather than a localised process, for it was also found in cartilage from peripheral osteophytes. Histo-autoradiographic studies showed that the osteoarthrotic chondrocytes are metabolically hyperactive all over the femoral head, including wedge-shaped margins of the zone of exposed bone. These results support the hypothesis that much of the articular cartilage fron osteoarthrotic femoral heads is of an immature chondroblastic type. It is suggested that de-nove synthesis of articular cartilage occurs during the process of regional remodelling of the femoras head, which would account for the observed hyperactivity.

In 1960 Collins and $\mathrm{McElligott}^{1}$ reported an increased capacity of human osteoarthrotic cartilage to fix radioactive sulphate which had been used as an indicator of the glycosaminoglycan synthesis. This was a rather surprising finding. Hitherto osteoarthrosis had been thought to be a degenerative disease of articular cartilage resulting from the progressive age related failure of this tissue to meet the functional demands for its continuing metabolic repair, especially when subjected to increased mechanical stress. Similar results on human femoral head cartilage were later published..$^{2-5}$ It was found that not only ${ }^{35} \mathrm{~S}$-sulphate but also ${ }^{3} \mathrm{H}$-glycine, ${ }^{3} \mathrm{H}$-cytidine, and ${ }^{3} \mathrm{H}$-thymidine (indicative of protein, RNA, and DNA synthesis respectively) incorporation was significantly greater in osteoarthrotic than in normal tissue. In addition a positive correlation was found between the capacity of the cells to incorporate radioactive metabolic precursors and the severity of tissue damage as appreciated by the histological-histochemical grading system proposed by. Mankin et al. ${ }^{4}$

Accepted for publication 14 December 1979.

Correspondence to Dr D Mitrovic, INSERM Unit 18, 6 rue Guy Patin, 75010 Paris, France.
However, in recent years the real metabolic state of the articular cartilage in osteoarthrosis has again been questioned and controversial results published. ${ }^{6-9}$ The present controversy is of theorical importance. A decreased synthetic capacity of the osteoarthrotic chondrocytes would imply a degenerative cell related process as a cause of the disease; while an increased synthetic activity could be, among other possibilities, a cell response to the chronic injury.

The aim of this study was to: (1) reinvestigate the cartilage metabolism in normal and osteoarthrotic tissue on large numbers of tissue samples; (2) correlate synthetic capacity to the number of cells, which has not always been done in the previous studies; (3) compare metabolic activity in the weight-bearing and non-weighting-bearing areas of normal femoral head cartilage; and finally (4) correlate the metabolic activity of the osteo- $Q$ arthrotic femoral cartilage to the degree of damage.

\section{Materials and methods}

Articular cartilage from 8 osteoarthrotic femoral heads ( 7 female and 1 male, mean age of patients 
62 years, range 50 to 68 ) and 7 normal ( 6 female and 1 male, mean age of patients 70 years, range 54 to 85 ) has been studied. The femoral heads were obtained after hip surgery. The 'normal' femoral heads were all from patients who had suffered subcapital femoral fracture. All were operated on within 24 hours of the accident. The osteoarthrotic femoral heads were in an advanced stage of disease and exhibited the characteristic ulcerative lesion in the weight-bearing areas.

Immediately after surgical removal the femoral heads were wrapped in wet sterile gauze, placed in ice to minimise the tissue damage due to relative hypoxia and desiccation, and brought into the laboratory. Before the tissue was incubated approximately 1-2 hours had elapsed. Small segments with a side of 2-3 mm of noncalcified cartilage were removed with a surgical razor blade and collected in Petri dishes containing Ham's F-12 culture medium. During the time of harvesting, drying of the cartilage was avoided by pouring the culture medium on to a surface of the femoral head.

In normal femoral heads the fragments of articular cartilage were collected separately from the superior, anterior, posterior, and inferior aspects. In osteoarthrotic femoral heads they were similarly removed from: (1) normal-appearing articular cartilage whenever it existed in weight-bearing areas (superior, anterior, and posterior aspects); (2) fibrillated cartilage around the zone of exposed bone, usually at 0.5 to $1.5 \mathrm{~cm}$ from the margin of the latter; (3) the wedge-shaped cartilaginous margin of the area of exposed bone; (4) and the peripheral osteophytes.

The pooled cartilage fragments were randomly divided into small lots of 10 to 15 tissue pieces. Duplicate samples were then incubated at $37^{\circ} \mathrm{C}$ in the plastic culture flasks containing $3 \mathrm{ml}$ of Ham's F-12 culture medium to which were added $100 \mathrm{IU} / \mathrm{ml}$ of penicillin and $50 \mu \mathrm{g} / \mathrm{ml}$ of streptomycin.

The material was first incubated for 1 hour: after 1 hour the medium was removed and fresh medium containing the isotopes was added. The radioactive media were prepared by dissolving ${ }^{35} \mathrm{~S}-\mathrm{Na}_{2} \mathrm{SO}_{4}$ (carrier free) and ${ }^{3} \mathrm{H}$-glycine (specific activity $5 \cdot 3 \mathrm{Ci} / \mathrm{mmol}$ ) and adjusting their concentrations as close as possible to $1 \mu \mathrm{Ci}$ and $5 \mu \mathrm{Ci}$ per $\mathrm{ml}$ respectively.

The incubations carried out for 2 and 4 hours were performed in $3 \mathrm{ml}$ of culture medium, while those carried out for 18 and 24 hours were performed in $6 \mathrm{ml}$ of the medium. The incorporation of the isotopes was stopped by rinsing the segments with 3 baths of cold saline (15 min each) and one bath of cold $80 \%$ ethanol (overnight). They were then dehydrated with 2 baths of absolute ethanol followed by 2 baths of ether, lyophilised and weighed.

The incorporated radioactivity was measured in an Intertechnique scintillation spectrometer after digestion of the fragments with $2 \mathrm{ml}$ of $1 \mathrm{~N} \mathrm{NaOH}$ at $60^{\circ} \mathrm{C}$ which was subsequently neutralised with an equivalent volume of $1 \mathrm{~N} \mathrm{HC1}$. The determinations were done on duplicate aliquots $(0.2 \mathrm{ml}$ each) dissolved in $10 \mathrm{ml}$ of Instagel. The results were calculated as disintegrations per minute (dpm)/mg of dry tissue and this value was than divided by the mean number of the cells $/ \mathrm{mm}^{2}$ counted on 1 or 2 representative samples of each incubated group of fragments.

The cells were counted on $10 \mu \mathrm{m}$ sections obtained by cutting deep-frozen samples in a cryostat. The sections were stained with haematoxylineosine and toluidine blue. The cell nuclei were counted with a Leitz specially designed eyepiece graticule in an area of $1 \mathrm{~mm}^{2}$. Each value was obtained from at least 30 countings performed on 5 sections representative of the entire fragment. The morphology and the degree of structural damage of cartilage was also observed and recorded.

One osteoarthrotic femoral head from a male 57years-old and one from a normal female 75-years-old were used for histo-autoradiographic study. The cartilage slices were incubated for 4 and 24 hours in Ham's F-12 culture medium to which radioactive sulphate (carrier free) was added to a final concentration of $20 \mu \mathrm{Ci} / \mathrm{ml}$. After thoroughly rinsing, the tissue was deep-frozen and cut in the cryostat. The $10 \mu \mathrm{m}$ thick sections were dipped into photographic Ilford K-5 emulsion, diluted with 2 volumes of warmed distilled water $\left(40^{\circ} \mathrm{C}\right)$, dried, and kept for a week free of moisture in light safety boxes. The sections were then processed in the dark room with Kodak D-19 developer and fixed with $20 \%$ hyposulphite.

The grains were counted on selected stained and unstained sections in different zones of cartilage under an immersion oil objective with the Leitz eyepiece graticule. The number of the grains was recorded for each single cell. That for clones was divided by the number of nuclei present in the clone.

\section{Results}

\section{Morphology of the cartilage samples}

A schematic representation of the gross morphology observed in most cases of osteoarthrotic femoral head cartilage is given in Fig. A. An oval or rounded zone of eburnated bone of variable dimensions was found on the articular surface of the weight-bearing areas, especially on the superior aspect of the femoral 

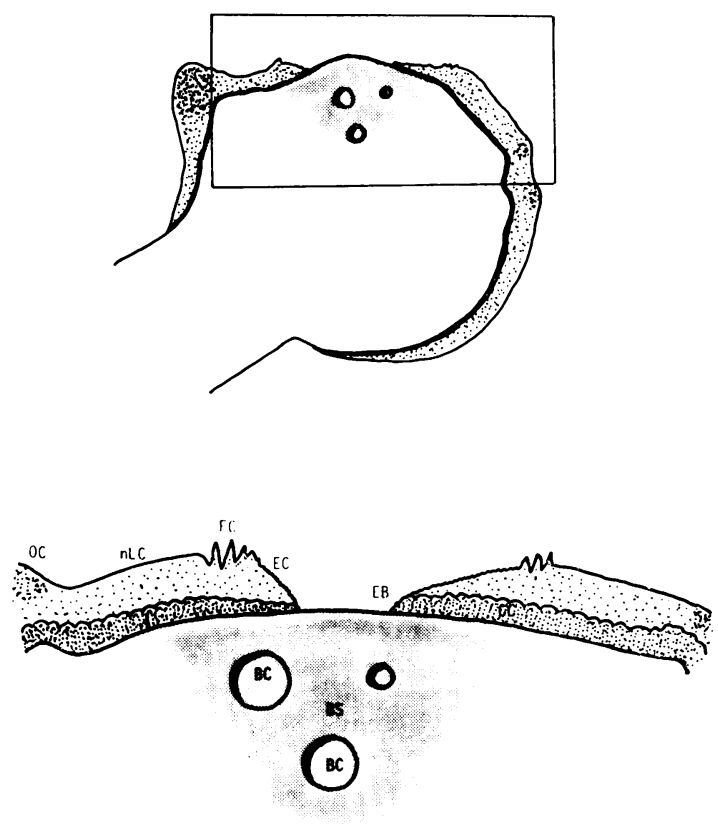

Fig. A Gross morphology observed in most cases of osteoarthortic femoral head cartilage. $B C=$ bone cysts. $B S=$ Haversian and trabecular bone sclerosis. $C C=$ calcified cartilage. $E B=$ exposed bone. $E C=$ eroded cartilage. $F C=$ fibrillated cartilage. $n L C=$ normal-appearing cartilage. $O C=$ osteophytic cartilage.

head. In some but not in all osteoarthrotic femoral heads the exposed bone was spotted with small plugs of fibrocartilaginous tissue arising from the subchondral bone. The cartilaginous margins of the ulceration were found to be of variable width usually narrower and with a sharper slope in the superior aspect than in the inferior part of the femoral head. This wedge-shaped abraded cartilage progressively merged into discoloured fibrillated and normal-appearing cartilage. At the periphery of the nonspherical and deformed head numerous marginal osteophytes covered with thin bluish cartilage were usually present.

The histology of the studied articular cartilage samples from normal and osteoarthritic femoral heads is given in Fig. 1-5. There is a gradual progression in the degree of the lesion in osteoarthrotic femoral head cartilage as one approaches the zone of exposed bone. Away from the latter, osteoarthrotic normal-appearing cartilage is not usually fibrillated but may lack its characteristic metachromasia (Fig. 2). The unstained superficial and stained deep zones seem to be sharply delimited. In this type of osteoarthrotic cartilage the cells are normally distributed within the tissue.

Closer to the zone of exposed bone (usually 0.5 to $1.5 \mathrm{~cm}$ ) the cartilage surface starts to fibrillate with the cells predominently arranged in clones (Fig. 3). The loss of metachromasia is more pronounced but still limited to the superficial and transitional layers of the articular cartilage. Deep vertical articular clefts are occasionally seen running down to the metachromatic cartilage. More often small clefts are present parallel and vertical to the articular surface. The deep metachromatic layer of cartilage seems to be normal. Superior abrupt margins of cartilage ulceration are generally composed of metachromatic cartilage similar to that observed in the deep zones. They have small cell clones and a relatively smooth surface resulting from

Fig. 1 Normal non calcified human femoral head cartilage from a weight-bearing area of the 67-year-old female who had suffered subcapital fracture.

(Haematoxyline-eosin, $\times 110)$.

Fig. 2 Normal-appearing (by eye inspection) osteoarthrotic 'primitive' hyaline femoral head cartilage of the 74-year-old female. (Toluidine blue. Note loss of metachromasia on the articular side of the tissue. $\times 160$ ).

Fig. 3 Fibrillated osteoarthrotic femoral head cartilage removed at $1.5 \mathrm{~cm}$ from the zone of the bone exposure of a 75-year-old female. (Haematoxylineeosin. Note surface fibrillation, loss of staining, and cloning of the cells. $\times 290)$.

Fig. 4 Osteoarthrotic wedge-shaped cartilage removed from a margin of a zone of exposed bone (arrow) in the 74-year-old female. Note the progresssive fraying and abrasion of the superficial achromatic laver of the cartilage. At the very end (right-hand side of the figure) the margin is formed by the deep metachromatic portion of cartilage. (Toluidine blue, $\times 90$ ).

Fig. 5 Osteoarthrotic wedge shaped cartilage removed from a margin of exposed bone (arrow) in the 79-yearold female. Note relatively smooth progressively abraded surface with many vertical shallow identations. (Haematoxyline-eosin, $\times 60$ ).

Fig. 6 Osteoarthrotic femoral head cartilage of a 57-year-old male. The tissue was incubated for 24 hours with radioactive sulphate and processed for histo-autoradiography as indicated in methods. Note 3 hyperactive and 1 inactive (arrow) cells. (Imm. obj. $\times$ 1100 ).

Fig. 7 Histo-autoradiography of the same case as in the Fig. 6. Osteoarthrotic wedge shaped cartilage from a margin of exposed bone (arrow). Note the actively synthesising cells all over the cartilage, including the very end of abraded tissue. The surface, as in Fig. 5, is irregular with small identations. $(\times 90)$. 

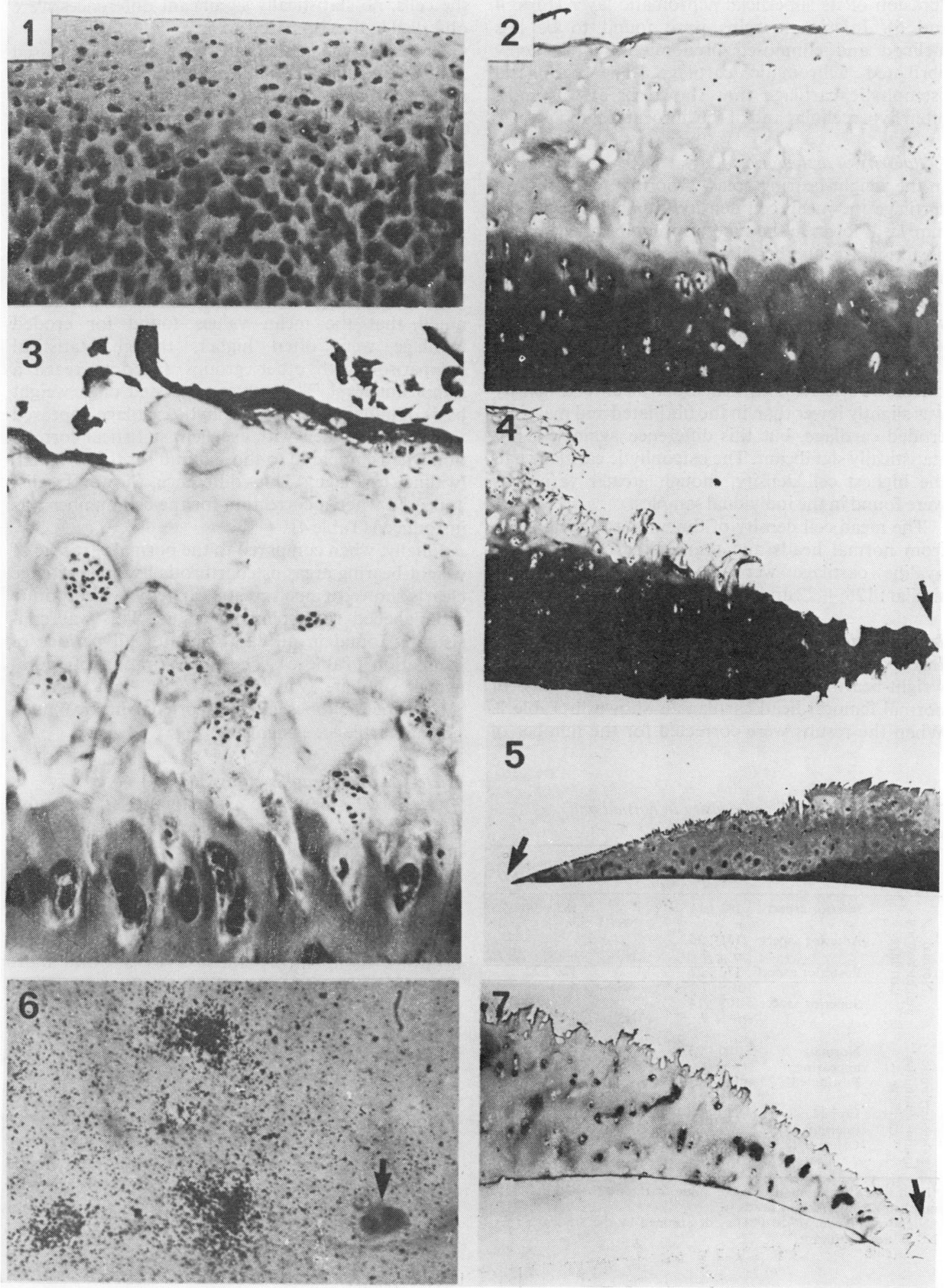
abrasion of its superficial achromatic layer (Figs. 4 and 5). Inferior margins were found to be less inclined and composed predominantly of deeply fibrillated achromatic cartilage. The peripheral osteophytic cartilage (not shown here) was most often hypercellular and of the fibrocartilaginous type.

\section{Cellularity of articular cartilage}

In the weight-bearing areas of normal femoral head cartilage the mean cell density (number of cells per $\mathrm{mm}^{2}$ ) was lower in the superior than the anterior and posterior aspects, but this difference did not reach statistical significance (Table 1). The cell density of the non-weight-bearing areas in the inferior aspect was clearly higher than that in the weight-bearing areas, with an excellent statistical correlation.

In the normal-appearing hyaline cartilage of the osteoarthrotic femoral heads the mean cell density was slightly lower than in the fibrillated and marginal eroded cartilage, but this difference again was not statistically significant. The osteophytic cartilage had the highest cell density, though greater variations were found in the individual samples.

The mean cell density of the weight-bearing areas from normal heads and that of the osteoarthrotic hyaline cartilage were found to be essentially similar: $126 \pm 22$ and $111 \pm 28$, respectively.

\section{Incorporation of the isotopes}

Incorporation of ${ }^{35} \mathrm{~S}$-sulphate and ${ }^{3} \mathrm{H}$-glycine in weight-bearing and non-weight-bearing areas of normal femoral head cartilage is shown in Table 2. When the results were corrected for the number of

Table 1 The overall cell density in normal and osteoarthrotic human femoral heads

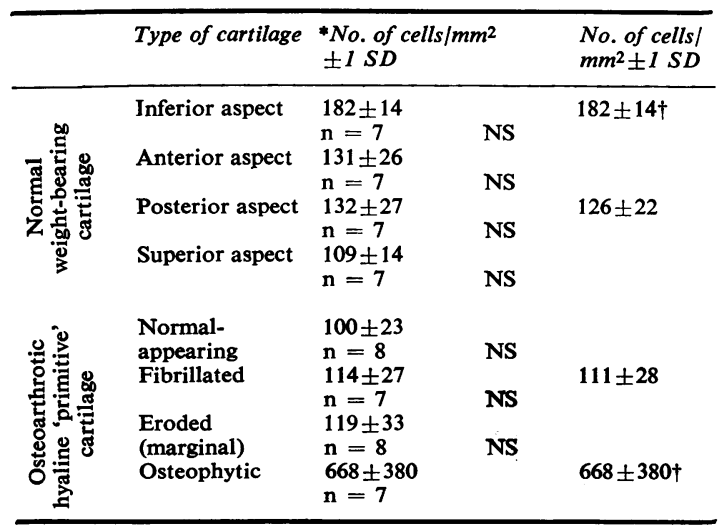

*Each figure represents the mean value of the means (30 individual numbers) from different heads ( $n$ ).

$\dagger$ Highly significant $(P<0 \cdot 001)$ as determined by the Student's $t$ test. NS $=$ not significant the cells, no statistically significant differences were observed in the compared areas.

However, when the results were merely expressed as disintegrations per minute $(\mathrm{dpm}) / \mathrm{mg}$ of dry weight of tissue (not shown), the incorporation appears to be much higher in the non-weight-bearing areas than in the weight-bearing ones because of much higher mean cell density $(182 \pm 14$ and $126 \pm 22$ respectively).

The osteoarthrotic hyaline cartilage fixed approximately the same amount of both isotopes regardless of the method of calculation, the degree of damage observed, and its anatomical location with respect to the zone of exposed bone (Table 3). It should be noted that the mean values found for eroded cartilage were often higher, though statistical comparison with other groups failed to reach a significant level. The values expressed on a weight basis obtained for the osteophytic cartilage appeared to be much higher, with excellent statistical correlation when compared to those found for the 'original' hyaline cartilage. This difference, however, disappeared when a correction for the cell number was introduced (Table 4).

Finally, when compared to the normal cartilage of weight-bearing areas osteoarthrotic hyaline cartilage clearly showed a much greater capacity to incorporateon radiolabelled metabolic precursors. This was con sistently found in all cases and for all periods of incubation (Table 5). The incorporation of radioactive sulphate was about twice and that of ${ }^{3} \mathrm{H}$-glycine $2-5$ times greater in osteoarthrotic than in normal cartilage segments.

\section{Histo-autoradiographic study}

The above metabolic investigations are also supported by observations from histo-autoradiographic studies performed on the cartilage segments from one normal and one osteoarthrotic femoral head. Incubated under the same conditions with respect to duration and isotopic concentration and processed in the same manner, the cells from osteoarthrotic tissue incorporated 2 to 3 times more ${ }^{35}$ S-sulphate than did the cells from normal cartilage (Table 6). This was particularly evident in zones 1 and 2, where a high level of statistical significance was reached.

In addition this study showed in both cases evidence for the metabolic heterogeneity of the chondrocytes. In normal cartilage all intermediates were seen from a completely inactive to a hyperactive cell. Approximately half the cells were found to be inactive, with slightly more active cells in the transitional zone.

In osteoarthrotic cartilage the cells from zones 
Table 2 Incorporation of ${ }^{35} \mathrm{SO}_{4}$ and ${ }^{3} \mathrm{H}$-glycine by the articular cartilage segments removed from weight-bearing and non-weight-bearing areas of normal human femoral heads

\begin{tabular}{|c|c|c|c|c|c|c|}
\hline \multirow{3}{*}{$\begin{array}{l}\text { Incubation in time } \\
\text { Isotope }\end{array}$} & \multicolumn{6}{|c|}{ Mean dpm/mg dry weight/mean number of cells $/ \mathrm{mm}^{2} \pm 1 S D$} \\
\hline & \multicolumn{2}{|l|}{2 hours } & \multicolumn{2}{|l|}{4 hours } & \multicolumn{2}{|l|}{24 hours } \\
\hline & ${ }^{35} \mathrm{SO}_{4}$ & ${ }^{3} H$-glycine & $35 \mathrm{SO}_{4}$ & ${ }^{3} H$-glycine & ${ }^{35} \mathrm{SO}_{4}$ & ${ }^{3} H$-glycine \\
\hline $\begin{array}{l}\text { Weight-bearing-areas } \\
\text { Sup. + ant. + post. aspect } \\
\text { Non-weight-bearing areas } \\
\text { Inferior aspect }\end{array}$ & $\begin{array}{l}4 \cdot 31 \pm 1 \cdot 54 \\
n=15 \\
4 \cdot 33 \pm 1 \cdot 56 \\
n=3 \\
N S\end{array}$ & $\begin{array}{l}7 \cdot 62 \pm 4 \cdot 15 \\
n=12 \\
5 \cdot 61 \pm 3 \cdot 23 \\
n=3 \\
\text { NS }\end{array}$ & $\begin{array}{l}7 \cdot 41 \pm 3 \cdot 3 \\
\mathrm{n}=10 \\
7 \cdot 19 \pm 1 \cdot 5 \\
\mathrm{n}=3 \\
\mathrm{NS}\end{array}$ & $\begin{array}{l}12 \cdot 00 \pm 4 \cdot 7 \\
n=9 \\
11 \cdot 46 \pm 1 \cdot 6 \\
n=3 \\
\text { NS }\end{array}$ & $\begin{array}{l}38 \cdot 8 \pm 14 \cdot 6 \\
n=17 \\
38 \cdot 5 \pm 24 \cdot 7 \\
n=3 \\
N S\end{array}$ & $\begin{array}{l}133 \pm 39 \\
n=12 \\
170 \pm 25 \\
n=3 \\
N S\end{array}$ \\
\hline
\end{tabular}

NS $=$ non-significant as determined by the Student's $t$ test. dpm $=$ Disintegrations per minute

Table 3 Incorporation of ${ }^{35} \mathrm{SO}_{4}$ and ${ }^{3} \mathrm{H}$-glycine by the articular cartilage segments from osteoarthrotic human femoral heads

\begin{tabular}{|c|c|c|c|c|c|c|c|}
\hline \multirow{4}{*}{ 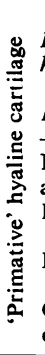 } & \multirow{3}{*}{$\begin{array}{l}\text { Incubation in } \\
\text { hours } \\
\text { Isotope }\end{array}$} & \multicolumn{6}{|c|}{ Mean dpm/mg of dry weight $\pm 1 S D$} \\
\hline & & \multicolumn{2}{|l|}{2 hours } & \multicolumn{2}{|l|}{4 hours } & \multicolumn{2}{|l|}{24 hours } \\
\hline & & ${ }^{35} \mathrm{SO}_{4}$ & ${ }^{3} \mathrm{H}$-glycine & ${ }^{35} \mathrm{SO}_{4}$ & ${ }^{3}$ H-glycine & ${ }^{35} \mathrm{SO}_{4}$ & ${ }^{3} \mathrm{H}$-glycine \\
\hline & $\begin{array}{l}\text { Normal- } \\
\text { appearing } \\
\text { Fibrillated } \\
\text { Eroded } \\
\text { Oesteophytic } \\
\text { cartilage }\end{array}$ & $\begin{array}{l}1 \cdot 826 \pm 749 \\
n=5 \\
1 \cdot 661 \pm 522 \\
n=5 \\
3 \cdot 177 \pm 2 \cdot 114 \\
n=4 \\
4 \cdot 082 \pm 1 \cdot 578^{*} \\
n=5\end{array}$ & $\begin{array}{l}5 \cdot 328 \pm 3 \cdot 728 \\
\mathrm{n}=7 \\
3 \cdot 728 \pm 2 \cdot 077 \\
\mathrm{n}=5 \\
7 \cdot 680 \pm 6 \cdot 545 \\
\mathrm{n}=5 \\
15 \cdot 697 \pm 7 \cdot 186^{*} \\
\mathrm{n}=4\end{array}$ & $\begin{array}{l}2 \cdot 314 \pm 504 \\
\mathrm{n}=7 \\
2 \cdot 320 \pm 1 \cdot 296 \\
\mathrm{n}=6 \\
2 \cdot 397 \pm 1 \cdot 144 \\
\mathrm{n}=8 \\
7 \cdot 153 \pm 3 \cdot 197^{* * *} \\
\mathrm{n}=6\end{array}$ & $\begin{array}{l}8 \cdot 720 \pm 6 \cdot 442 \\
\mathrm{n}=7 \\
6 \cdot 933 \pm 2 \cdot 597 \\
\mathrm{n}=7 \\
10 \cdot 435 \pm 3 \cdot 997 \\
\mathrm{n}=8 \\
38 \cdot 655 \pm 19 \cdot 804^{* *} \\
\mathrm{n}=4\end{array}$ & $\begin{array}{l}10 \cdot 078 \pm 2 \cdot 140 \\
n=4 \\
11 \cdot 635 \pm 3 \cdot 089 \\
n=3 \\
18 \cdot 744 \pm 13 \cdot 509 \\
n=3 \\
30 \cdot 057 \pm 13 \cdot 771^{* *} \\
n=7\end{array}$ & $\begin{array}{l}48 \cdot 843 \pm 12 \cdot 512 \\
n=3 \\
44 \cdot 453 \pm 10 \cdot 722 \\
n=4 \\
61 \cdot 136 \pm 19 \cdot 255 \\
n=4 \\
140 \cdot 876 \pm 68 \cdot 778^{*} \\
n=5\end{array}$ \\
\hline
\end{tabular}

$\mathrm{n}=$ number of osteoarthrotic femoral heads studied.

*Significant $(\mathrm{P}<0.02)$ as determined by the Student's $t$ test. ${ }^{* *}$ Very significant $(\mathrm{P}<0.01)$. ${ }^{* *}$ Highly significant $(\mathrm{P}<0.001)$.

Table 4 Incorporation of ${ }^{35} \mathrm{SO}_{4}$ and ${ }^{3} \mathrm{H}$-glycine by the articular cartilage segments removed from the osteoarthrotic human femoral heads and osteophytes

\begin{tabular}{|c|c|c|c|c|c|c|}
\hline \multirow{3}{*}{$\begin{array}{l}\text { Incubation time } \\
\text { Isotope }\end{array}$} & \multicolumn{6}{|c|}{ Mean $\mathrm{dpm} / \mathrm{mg}$ dry weight/number of cells/mm $\mathrm{mm}^{2} \pm I S D$} \\
\hline & \multicolumn{2}{|l|}{2 hours } & \multicolumn{2}{|l|}{4 hours } & \multicolumn{2}{|l|}{24 hours } \\
\hline & $35 \mathrm{SO}_{4}$ & ${ }^{3}$ H-glycine & $35 \mathrm{SO}_{4}$ & ${ }^{3} H$-glycine & $35 \mathrm{SO}_{4}$ & ${ }^{3} H$-glycine \\
\hline $\begin{array}{l}\text { Hyaline 'primative' cartilage } \\
\text { Osteophytic cartilage }\end{array}$ & $\begin{array}{l}12 \cdot 9 \pm 5 \cdot 2 \\
n=17 \\
10 \cdot 9 \pm 7 \cdot 6 \\
n=5 \\
N S\end{array}$ & $\begin{array}{l}39 \cdot 0 \pm 20 \cdot 0 \\
n=14 \\
26 \cdot 2 \pm 12 \cdot 6 \\
n=5 \\
N S\end{array}$ & $\begin{array}{l}17 \cdot 4 \pm 8 \cdot 6 \\
n=22 \\
23 \cdot 3 \pm 12 \cdot 6 \\
n=4 \\
N S\end{array}$ & $\begin{array}{l}75 \cdot 6 \pm 49 \cdot 0 \\
n=19 \\
94 \cdot 6 \pm 63 \cdot 2 \\
n=4 \\
N S\end{array}$ & $\begin{array}{l}71 \cdot 6 \pm 44 \cdot 2 \\
\mathrm{n}=19 \\
113 \cdot 8 \pm 52 \cdot 4 \\
\mathrm{n}=5 \\
\mathrm{NS}\end{array}$ & $\begin{array}{l}400 \pm 164 \\
n=16 \\
463 \pm 281 \\
n=4 \\
N S\end{array}$ \\
\hline
\end{tabular}

NS = non-significant as determined by the Student's $t$ test.

Table 5 Incorporation of ${ }^{35} \mathrm{SO}_{4}$ and ${ }^{3} \mathrm{H}$-glycine by the articular cartilage segments from normal and osteoarthrotic human femoral heads

\begin{tabular}{|c|c|c|c|c|c|c|c|c|}
\hline \multirow{3}{*}{ Incubation time } & \multicolumn{8}{|c|}{ Mean dpm/mg dry weight/number of cells/mm $m^{2} \pm 1 S D$} \\
\hline & \multicolumn{2}{|l|}{2 hours } & \multicolumn{2}{|l|}{4 hours } & \multicolumn{2}{|l|}{18 hours } & \multicolumn{2}{|l|}{24 hours } \\
\hline & ${ }^{35} \mathrm{SO}_{4}$ & ${ }^{3} \mathrm{H}$-glycine & ${ }^{35} \mathrm{SO}_{4}$ & ${ }^{3} \mathrm{H}$-glycine & ${ }^{35} \mathrm{SO}_{4}$ & ${ }^{3} H$-glycine & ${ }^{35} \mathrm{SO}_{4}$ & ${ }^{3} H$-glycine \\
\hline $\begin{array}{l}\text { Normal cartilage from } \\
\text { weight-bearing areas } \\
\text { Osteoarthrotic hyaline } \\
\text { cartilage } \\
\text { Student's } t \text { test }\end{array}$ & $\begin{array}{l}4 \cdot 31 \pm 1 \cdot 54 \\
\mathrm{n}=15 \\
12 \cdot 90 \pm 5 \cdot 20 \\
\mathrm{n}=17 \\
* * *\end{array}$ & $\begin{array}{l}7 \cdot 62 \pm 4 \cdot 15 \\
n=12 \\
39 \cdot 00 \pm 20 \cdot 00 \\
n=14 \\
* * *\end{array}$ & $\begin{array}{l}7 \cdot 41 \pm 3 \cdot 3 \\
n=10 \\
17 \cdot 40 \pm 8 \cdot 6 \\
n=23 \\
* *\end{array}$ & $\begin{array}{l}12 \cdot 0 \pm 4 \cdot 7 \\
n=9 \\
75 \cdot 6 \pm 49 \cdot 0 \\
n=19 \\
* * *\end{array}$ & $\begin{array}{l}27 \cdot 8 \pm 9 \cdot 2 \\
n=15 \\
56 \cdot 6 \pm 45 \cdot 1 \\
n=12 \\
* *\end{array}$ & $\begin{array}{l}116 \pm 38 \\
n=12 \\
246 \pm 69 \\
n=8 \\
* * *\end{array}$ & $\begin{array}{l}38 \cdot 8 \pm 14 \cdot 6 \\
\mathrm{n}=17 \\
71 \cdot 6 \pm 44 \cdot 2 \\
\mathrm{n}=19 \\
* *\end{array}$ & $\begin{array}{l}133 \pm 39 \\
n=12 \\
400 \pm 164 \\
n=16 \\
* * *\end{array}$ \\
\hline
\end{tabular}

**Very significant $(\mathrm{P}<0 \cdot 01) .{ }^{* * *}$ Highly significant $(\mathrm{P}<0.001)$. 
Table 6 Histo-autoradiographic evaluation of incorporation of ${ }^{35}$ so 4 in different zones of normal and diseased cartilage*

\begin{tabular}{|c|c|c|c|c|}
\hline \multirow[b]{2}{*}{ Zone } & \multicolumn{2}{|l|}{ Normal $\dagger$} & \multicolumn{2}{|l|}{ Arthrotic } \\
\hline & $\begin{array}{l}\text { Mean no. of } \\
\text { grains/cell } \\
\pm 1 S D\end{array}$ & $\begin{array}{l}\text { Active } \\
\text { cells in \% }\end{array}$ & $\begin{array}{l}\text { Mean no. of } \\
\text { grains/cell } \\
\pm 1 S D\end{array}$ & $\begin{array}{l}\text { Active } \\
\text { cells in } \%\end{array}$ \\
\hline $\begin{array}{l}\text { Superficial (zone } \\
\text { I } 100 \mu \mathrm{m} \text { from } \\
\text { surface) } \\
\text { Transitional } \\
\text { (zone II) } \\
\text { Radial } \\
\text { (zone III) }\end{array}$ & $\begin{array}{l}27 \pm 40 \ddagger \\
\mathrm{n}=50 \\
\mathrm{P}<0 \cdot 001 \\
76 \cdot 6 \pm 76 \ddagger \\
\mathrm{n}=71 \\
52 \cdot 5 \pm 71 \\
(\mathrm{NS}) \\
\mathrm{n}=67\end{array}$ & $\begin{array}{l}62 \% \\
46 \%\end{array}$ & $\begin{array}{l}89-5 \pm 50 \ddagger \\
n=37 \\
166 \pm 120 \ddagger \\
n=29 \\
66 \cdot 68 \text { (NS) } \\
n=60\end{array}$ & $\begin{array}{l}100 \% \\
99 \% \\
75 \%\end{array}$ \\
\hline
\end{tabular}

*All cells were counted: active + inactive (less than 10 grains/cell); osteoarthrotic cartilage was of hyaline type with an intact surface.

†The figures obtained for each zone of normal were compared with those from the corresponding zone of osteroarthrotic cartilage.

†Highly significant, $\mathrm{P}<0.001$ as determined by the Student's $t$ test. NS = not significant

1 and 2 were practically all active but to a variable degree. In the zone 3 the proportion of active cells was higher than in normal cartilage, though about $25 \%$ of the cells remained inactive (Table 6 and Fig. 6).

At the sites where the cells have gathered in clones the latter exhibited various degrees of activity. Large variations in the amount of the incorporated isotope by each single cell within a clone were also seen. This was equally true of the eroded wedge-shaped cartilage, which appeared to be very active (Fig. 7).

\section{Discussion}

The results of the present study strongly support the already postulated hypothesis that in osteoarthrotic femoral heads the chondrocytes are the hyperactive matrix producing cells. The data presented here are in good agreement with those previously published. ${ }^{1-59}$ But they are in disagreement with some recently reported. ${ }^{7810}$

The reasons for these discrepancies are not clear. Methodological differences might occasionally be of importance-for instance, when dialysis is used after papain digestion of the samples to be counted in order to remove incorporated sulphate. ${ }^{10}$ This procedure might have removed from the osteoarthrotic digests a relatively higher proportion of the small polysaccharide molecules ${ }^{11}$ resulting from an increased catabolic activity of the cells or from an impared synthesis. Such an increased catabolism in osteoarthrosis is suspected on the basis of several studies which have reported a higher lysosomal content in osteoarthrotic articular cartilage. ${ }^{12-14}$

Differences in the choice of the experimental and control materials might also induce variations in the observed results. Articular cartilage from osteoarthrotic and fractured human femoral heads has been used by authors who have reported both an increased $^{3-5}$ and decrease ${ }^{810}$ metabolism in osteoarthrosis. Higher incorporation rates of metabolic radiolabelled precursors were also seen in patellar ${ }^{1}$ and knee joint ${ }^{9}$ osteoarthrotic cartilage.

Other parameters such as precise conditions of transportation and handling of the experimental material with respect to the time that had elapsed after surgery and before incubation could be critical. The use of anti-inflammatory drugs by the osteoarthrotic patients for many years prior to surgery might also have influenced the metabolism of the chondrocytes, ${ }^{6}$ though one would then expect inhibited rather than increased metabolic activity of the osteoarthrotic tissue.

The use of articular cartilage from surgically removed fractured femoral heads as a reference to the normal cartilage metabolism may be questioned. Although little is known about the effects of acute trauma, ischaemia, hypertension, and blood changes (due to intra-articular haematomas) they all might be of importance with respect to the cartilage metabolism.

Relevant to this study are some investigations o cartilage metabolism in different forms of osteo of arthrosis in animals. In naturally occurring osteroarthrosis of the hip joint in dogs, protein and RNA synthesis were found to be depressed, ${ }^{15}$ while in the experimentally induced osteoarthrosis of the $\mathrm{dog},{ }^{16}$ rabbit, ${ }^{17} 18$ and sheep ${ }^{19}$ protein and glycosaminoglycan synthesis were found to be higher than in normal cartilage.

Incorporation of ${ }^{35} \mathrm{SO}_{4}$ have been used many times to measure the glycosaminoglycan synthesis in cartilage, ${ }^{720}$ and it has been shown in our laboratory that $95-98 \%$ of the label is present in the proteoglycan fraction after an extraction of prelabelled bovine articular cartilage with $4 \mathrm{M}$ guanidinium HCL. ${ }^{21}$ The incorporation of tritiated glycine is indicative of the synthesis of intra- and extracellular proteins. In cartilage these proteins are mainly extracellular, such as collagen, glycoproteins, and proteoglycan core protein..$^{22}$

Theoretically it is not possible simply to equate the incorporation of the labelled metabolic pre- N cursors with the synthesis of the given macromolecules. The sizes of their extra- and intracellular pools, the diffusion rates, concentration equilibria, $\frac{D}{D}$ transport mechanisms, availability of the substrates, $\stackrel{\infty}{+}$ and metabolic cofactors, etc. have to be kept under 0 precise control. However, under the experimental 0 conditions in vitro, and when longer periods of incubation are used, many of these unknown factors are minimised, and thus it is resonable to assume that 
the incorporation measures mainly the synthesis of a given macromolecule. The increased synthesis, however, does not mean an accumulation of the manufactured product, for it might be counterbalanced by an increased catabolism with even a net loss of the product. This might well be the case in osteoarthrosis, where it was shown that the glycosaminoglycan concentration is decreased ${ }^{3-5} 7112324$ and the content of lyzosomal enzymes increased. ${ }^{12-14} 25$

The cell density of normal femoral head cartilage appeared to be at least $50 \%$ higher in none-weightbearing areas than in the weight-bearing areas, which is in good agreement with the results of Vignon et $a .^{26}$ and is thought to be related to cartilage thickness. ${ }^{27} 28$

The cell density of osteoarthrotic hyaline cartilage seems to be very similar to that of the corresponding normal tissue. It does not change appreciably with the degree of cartilage damage in spite of intense cell proliferation and cloning. That means that a very precise regulatory mechanism operates in arthrotic articular cartilage to compensate for increased cell loss due to cell necrosis or mechanial attrition of the tissue. These results are also in agreement with the DNA determinations ${ }^{5}$ and cell count ${ }^{826}$ performed on the osteoarthrotic human femoral head cartilage.

When related to the cell density, the metabolic activity of normal cartilage is found to be the same in all parts of the fractured femoral head. This is rather surprising, for mechanical factors are thought to be important for articular cartilage metabolism.

Thickness of articular cartilage is found to be increased in the load bearing areas of the joints, ${ }^{29}$ while mechanical stimulation over several months was reported to enhance proteoglycan synthesis in rabbit $^{18}$ and sheep ${ }^{19}$ articular cartilage but not in limb skeleton of rats. ${ }^{30}$ Since in this study the fractured femoral heads were removed within 24 hours, this is may be not an important factor.

Histo-autoradiographic quantitative analysis performed on 1 osteoarthrotic and 1 normal femoral head is in agreement with metabolic data reported in present study. It shows clearly that both the mean number of grains per cell and number of active cells are increased in osteoarthrotic cartilage, especially in the superficial and intermediate zones. This is in disagreement with the hypothesis that increased metabolic activity seen in osteoarthrotic tissue is apparent and due to a reduction of the number of superficial cells ${ }^{8}$ which are metabolically less active. The present data suggest that diseased tissue is indeed in a hyperactive state.

The absence of a graded metabolic response to the degree of tissue damage in osteoarthrotic cartilage contradicts previously reported data ${ }^{4} 5$ and does not support the response theory of a hyperactive injured cell. As a working hypothesis it is possible that the hyaline cartilage found at the surface of most of the osteoarthrotic femoral heads is no longer the original primitive cartilage but the new tissue formed in the course of the remodelling process of the entire region. It thus presents analogies with the cartilage that covers the osteophytes. In support of this theory one can argue that in many osteoarthrotic femoral heads a pannus-like tissue is found gliding on the surface of the hyaline cartilage from the periphery inside the joint. Both tissues, pannus and hyaline cartilage, progressively merge, and there is no doubt that this represents part of a reconstructive phenomenon. In addition this view is also supported by the biochemical differences found in the composition of the normal adult and osteoarthrotic articular cartilage. The latter, like young immature tissue, is richer in chondroitin- 4 and has a higher chondroitin sulphate/keratan sulphate ratio. ${ }^{16} 3132$

Likewise, the finding in this study that osteoarthrotic (osteophytic and 'primitive' hyaline cartilage) is metabolically more active than normal cartilage is in keeping with this hypothesis. It is therefore evident that the study of osteoarthrosis must focus on the early stages of disease in order to shed more light on the nature of the morbid process. Recent studies on experimental animals are in that respect very promising.

We are greatful to Professor Witwoët for providing us with some resected femoral heads and to Mr Alan Norden for his advice during preparation of the manuscript.

This work was supported by grants ATP No. 6978101 and CRL 75.5.043 of INSERM.

\section{References}

${ }^{1}$ Collins D H, McElligott T F. Sulfate $\left({ }^{3} \mathrm{SO}_{2}\right)$ uptake by the chondrocytes in relation to histological changes in osteoarthritic human articular cartilage. Ann Rheum Dis $1960 ; 19$ : 318-22.

2 Bollet A J. Stimulation of protein-chondroitin sulfate synthesis by normal and osteoarthritic cartilage. Arthritis Rheum 1968; 11: 663-73.

3 Mankin H J, Lippiello L. Biochemical and metabolic abnormalities in articular cartilage from osteoarthritic human hips. J Bone Joint Surg 1970; 52A : 424-34.

4 Mankin H J, Dorfman H, Lippiello L, Zarins A. Biochemical and metabolic abnormalities in articular cartilage from osteoarthritic human hips. $J$ Bone Joint Surg 1971; 53A: 523-37.

5 Mankin H J, Lipipello L. The glycosaminoglycans of normal and arthritic cartilage. J Clin Invest 1971; 50: 1712-9.

6 McKenzie L S, Horsburg B A, Gosh P, Taylor T K F. Effect of anti-inflammatory drugs on sulphated glycosaminoglycan synthesis in aged human articular cartilage. Ann Rheum Dis 1976; 35: 487-97. 
7 Maroudas A. Glycosaminoglycan turnover in articular cartilidge. Philos Trans $R$ Soc Lond (Biol) 1975; B 271: 293-313.

8 Byers P D, Maroudas A, Oztop F, Stockwell R A, Venn M F. Histological and biochemical studies on cartilage from osteoarthrotic femoral heads with special reference to surface characteristics. Connect Tissue Res 1977; 5: 41-9.

9 Jacoby R K, Jayson M I V. The organ culture of adult human articular cartilage, from patients with osteoarthrosis. Rheum atol Rehabil 1976; 15: 116-22.

10 McKenzie L S, Horsburg B A, Gosh P, Taylor T K F. Sulphated glycosaminoglycan synthesis in normal and osteoarthritic hip cartilage. Ann Rheum Dis 1977: 36: 369-73.

11 Vignon E, Arlot M, Chapuy M C, Richard M, Luisot P, Vignon G. Etude de la concentration en glycosaminoglycanes du cartilage de la tête fêmorale normale et arthrosique. Pathol Biol (Paris) 1975; 23: 283-9.

12 Ehrlich M G, Mankin H J, Treadwell B V. Acid hydrolase activity in osteoarthritic and normal human cartilage. J Bone Joint Surg 1973; 55A: 1068-76.

13 Sapolski A I, Howell D S, Woessner F J. Neutral proteases and Cathepsin D in human articular cartilage. $J$ Clin Invest 1974; 53: 1044-53.

14 Howell D S. Degradative enzymes in osteoarthritic human articular cartilage. Arthritis Rheum 1975; 18: 167-77.

15 Mankin H J, Laing P. Protein and ribonucleic acid synthesis in articular cartilage of osteoarthritic dogs. Arthritis Rheum 1967; 10: 444-50.

16 McDevitt C A, Muir H. Biochemical changes in the cartilage of the knee in experimental and natural osteoarthritis in the dog. $J$ Bone Joint Surg 1976; 58B: 94-101.

17 Mayor M B, Moskowitz R W. Metabolic studies in experimentally induced degenerative joint disease in the rabbit. $J$ Rheumatol 1974; 1 : 17-23.

18 Radin E, Ehrlich M G, Chernack R, Abernethy P, Paul I L, Rose R M. Effect of repetitive impact loading on the knee joints of rabbits. Clin Orthop 1978; 23: 283-9.
19 Caterson B, Lowther D A. Changes in the metabolism of the proteoglycans from sheep articular cartilage in response to mechanical stress. Biochem Biophys Acta $1978 ; 540$ : 412-22.

20 Mankin $H \mathrm{~J}$. The metabolism of articular cartilage in health and disease. In: Burleigh P M C, Poole A R, eds. Dynamics Con. Tiss. Macromol., p 327-353. Amsterdam: Elsevir, 1975: 434.

21 Swann D A, Mitrovic D, Demignon J. Age dependent differences in the extraction of in vitro labelled cartilage macromolecules. Fed Proc 1979; 38: 652.

22 Mitrovic D, Ryckewaert A. Structure et biologie du cartilage articulaire de l'adulte. Rev Rhum Mal Osteoartic 1978; 45: 535-40.

23 Bollet A J, Nance J L. Biochemical findings in normal and osteoarthritic articular cartilage. II-Chondroitin and chain length, water and ash content. J Clin Invest 1966; 45: 1170-7.

24 Hjertquist S O, Lemperg R. Identification and concentration of the glycosaminoglycans of human articular cartilage in relation to age and osteoarthritis. Calcit Tissue Res 1972; 10: 223-37.

25 Ali S Y, Evans L. Enzymatic degradation of cartilage in osteoarthritis. Fed Proc 1973; 32: 1494-8.

26 Vignon E, Arlot M, Patricot L M, Vignon G. The cell density of human femoral head cartilage. Clin Orthop 1976, Nov-Dec, 303-8.

27 Stockwell R A. The cell density of human articular and costal cartilage. J Anat $1967 ; 101$; 753-60.

28 Stockwell R A, Meachim G. The chondrocyte. In: Freeman M A R ed. Adult Articular Cartilage. New York Grune and Stratton 1972: 341.

29 Ekholm R, Ingelmark B E. Functional thickness variations of human articular cartilage. Acta Soc Med Upsalief 1952; 57: 39-42.

30 Slack G B. The metabolism of sulphated polysaccharides in limb atrophy in the rat. Biochem J 1955;60: 112-8.

31 Mankin $\mathrm{H}$ J. Biochemical and metabolic aspects of osteoartritis. Orthop Clin North Am 1971; 2: 19-31.

32 Sweet M B E, Thonar E J.-M A, Immelman A R, Solomon L. Biochemical changes in progressive osteoarthrosis. Ann Rheum Dis 1977: 36: 387-98. 